\title{
Behavioral Segmentation of Baby Food Consumers: Risk Areas, Possible Solutions. The Case of Ukraine
}

\author{
By Nina Shashkova ${ }^{1}$, Iuliia Ushkarenko ${ }^{2}$, Andrii Soloviov ${ }^{3}$, Oleksii Osadchyi ${ }^{4}$, \\ Vitalii Nitsenko ${ }^{5}$
}

\begin{abstract}
The concept of this work is based on the idea of the interrelation of socio-demographic factors and factors of enterprises strategic development (baby food producers). According to the key indicators, the main components identify the psychographic characteristics of baby food consumers. Each factor included features with the highest factor load after geometric rotation by the Varimax method. The most critical areas of social status, stereotypical representation, consumer standards are found, which signal urgent problems that can be solved only if efforts of public and private solutions are combined (Foresight design). Social PR projects are a possible solution for a long-term program to expand the domestic market for baby food. The mechanism of implementation is to provide an opportunity for enterprises producing baby food products to participate in the implementation of national and regional programs to support fertility and family policy in Ukraine. It is suggested to introduce the results of marketing analysis of psychographic segmentation of consumers of baby food products into Foresight-design programs. The study proposes to integrate the marketing communication policy of baby food manufacturers and government policies in the field of fertility support in Ukraine, based on the principles of Foresight engineering for the social projects implementation.
\end{abstract}

Keywords: psychographic, baby food consumers, social PR-projects, risks, foresight

\section{Introduction}

The main indicators of the domestic market development for baby food are the socio-demographic parameters that best characterize the state of society with the dynamically changing values of post-industrial existence. The development of the baby food industry is a priority for family values, that dominance values procreation. However, global statistics (according to the Institute for Health and Evaluations at the University of Washington) indicate that the total birth rate of half of the world is below the level of simple population reproduction (Gallagher, 2018). Thus, the total fertility rate in Ukraine is 1.37 children per one woman of reproductive age. However, at least zero reproduction is required for 2.33 children per woman of reproductive age. It is noteworthy that the

| '1Doctor of Economics Sciences, Professor, Head of the Department of Management and Administration, Kherson State University, Ukraine

2Doctor of Economics Sciences, Professor, Head of the Department of Economics and International Economic Relations, Kherson State University, Ukraine

${ }^{3}$ Doctor of Economics Sciences, Professor, Dean of the Economics and Management Faculty, Kherson State University, Ukraine

${ }^{4} \mathrm{Ph} . \mathrm{D}$. in Economics, Associate Professor of the Department of Economics and International Economic Relations, Kherson State University, Ukraine

${ }^{5}$ Doctor of Economics Sciences, Professor of the Department of Economics and Finance, Odessa National Maritime University, Ukraine 
number of live births from 2014 to 2017 decreased by 101.9 thousand people a year, when as a natural reduction is -210.1 thousand people (Ukraine population 2018, 2019).

World depopulation trends show the huge difference between birth rates in the midtwentieth century and birth rates at the beginning of the 21st century: 4.7 versus 2.4 children for the entire reproductive age of a woman. Ukraine maintains this figure at the European level, but with such complication: the number of deaths exceeds the number of births twice. In Western and Southern Europe, longer life expectancy and high numbers of immigrants offset low birth rates. Whereas Ukraine belongs to those countries in Europe with the shortest life expectancy (71.9 years in Ukraine, the EU average 83.6 years). A number of scientists have studied the social and psychological patterns of the consumer society: Baudrillard (1998), Slater (1999), Arnould and Thompson (2018) and others. Estimates and predictions converge in one thing: the priority of hedonistic values, the pragmatization of aspirations, the prerogative of the three "simulacra" " opinion, money" (Baudrillard, 1998) - ultimately leads to the degeneration of the physical and spiritual forces that are essential for the fulfillment of the most important human birth. Hence, it becomes clear that more informative in the problem of marketing analysis of the market of baby food products are not so much demographic, but psychographic characteristics of quality order: "childfree priority", "two children enough for a comfortable life", "I do not believe that there is enough money and strength, time, etc.", "I do not want to lose my job", "I have not completed my studies, "I do not want to ruin a figure", "I want to live for myself", "I better get a dog or an iguana" and others. By the way, neuromarketing studies highlight the concept of "sublimation of love" when the unpleasant (hypothetically difficult) birth and upbringing of children sublimates into a pleasant and less responsible business of caring for an animal. The pet goods and services industry in the United States grew from 17 billion in the mid-1990s to 72.56 billion in 2018 (75.38 billion estimated in 2019) (U.S. Pet Industry, 2019). According to the data from American Pet Products Association (APPA), \$1 billion goes to health insurance Market value of infant formula and baby food in North America in 2025 forecasted at level 21.1 billion U.S. dollars. Market value of infant nutrition worldwide in 2024 forecasted at level 98.8 billion U.S. dollars (Global infant nutrition market size, 2019).

These key indicators as a "reorientation interests of the family in professional activities", "economic independence of women", "the fear and insecurity" are the most important parameters in assessing consumer characteristics of potential buyers. Hence, the potential of the baby food consumer segment can be evaluated using a large number of observations using integral linguistic variables. The urgency of the work lies in the possibility of specification of abstract and difficult formalized categories of consumer sentiment, which will contribute to the development of a creative marketing program integrated into the state policy of overcoming the demographic crisis in Ukraine. This concept can be a successful Foresight project, which combines future planning and networking of participants: public authorities (non-commercial marketing), non-governmental institutions and baby food companies.

The purpose of this work is a multidimensional statistical evaluation of the psychographic features of segmentation of the baby food market, which may serve as a basis for:

- Development of marketing strategy of the enterprises of the given branch;

- Development of joint with state and non-state institutions Foresight project of 
overcoming the demographic crisis in Ukraine.

\section{Materials and Methods}

Dehumanizing aspects are manifested in the exploitation of psychological phenomena that promise successful sales, for example, gamification (engaging the consumer in the game form of interaction with business companies) (Eisingerich et al, 2019; Kleszczyński, 2019; Becker and Jaakkola, 2020), consumer relations with the brand as a person (Schmitt 2013), anthropomorphizing, pairing people with products (Allenby et al, 2002; Géczy et al, 2007; Hart and Royne, 2017; Heerah et al, 2017; Herak et al, 2020; Yang et al, 2020) etc.

The subject of meticulous attention is the phenomenon of consumer behavioral selfcontrol, rational conscious refusal from the tempt to make unnecessary purchases (Birkhead, 2001; Shah, 2008; Bearden and Kelly, 2012; Abdullah et al, 2012; Nguyen and Paswan, 2013).

It is no accident that the problem of consumer self-control is so fascinating to marketologists. After all, self-control and self-restraint prevent the purchase propensity to increase. Psychological research on the harmfulness of "abstinence" is quite consistent with the idea of unrestrained consumption. Yes, it is noted that one's ability to act actively is limited, and violence against one's will lead to "ego depletion" and the difficulty of exercising self-control in the future (Baumeister et al, 1998). The basis of Ego Depletion Effect - the comparison of willpower with muscles - the more the consumer exerts a willpower, the more fatigued the muscles. Weak willpower is a consequence of abstaining from temptation, during which the ego is depleted. Paradoxically, a consumer with fatigueresistant will is more likely to make purchases more often.

On the other hand, such a development in the field of cognitive psychology in combination with neurotechnology (of invasive and non-invasive nature) may be considered an anti-human method of marketing research. Let's look only at the concepts used in practice to understand with what consumer simplicity marketologists look into the depths of the sacred human nature, not just touching, but forcing the spiritual essence of person: "search from the consumer button" "buy", "blow the brain of the consumer", "how to influence consumer consciousness", "Inside the Mind of the Shopper" etc.

Neuromarketing has become a dangerous tool, first and foremost, for the reason that it is in the hands of a large mass of businessmen of dubious reputation. For example, a design school advertising lecturer will easily teach you how to manipulate hormones, not the nerves of consumers, through bright rollers. It speaks of the desacralization of humanity, the spiritual component of the consumer, and ultimately the endeavor for his mental health. Uncontrolled consumption becomes a state problem. Along with the growing trend of embracing materialistic worldview (Richins, 2017; Druzhynina et al, 2020), consumer self-control issues are seen as abstaining from hedonic consumption that's provides a rich set of implications for deducing interventions on the individual and public policy level to help consumers exert self-control (Scopelliti and Huh, 2020).

Therefore, public institutions should not be exempt from the problems of society dehumanization, since the sphere of traditional values and self-control is, in essence, a problem of national security. The article aims to find the points of consolidated interest 
of business structures and the state in the chain: "production of baby food - baby food market - consumers - social status, demographic problems". The issue of creating a comprehensive system of implementation of social events using foresight design methods is being updated.

This study set out to reveal the psychographic characteristics (intrinsic motivation of shopping) of consumers of baby food. The research was carried out at the Research Laboratory "Center of Forecasting and Planning Initiatives of Tavriya Region" of Kherson State University. The study was based on a combination of quantitative and qualitative methods for analyzing psychographic features that determine household consumption behavior in the context of extending the life cycle of a family with young children. Psychographic features of the baby food consumers' behavior (families of Kherson region (Ukraine)) were studied on the basis of the processing of questionnaire information. As the survey was of the nature of the survey of specific population groups of families with children under 8 years of age, full-nest type 1 consumers, the statistical sample was formed by the method of "snowball" when the respondent points to other known potential respondents. Here the condition of equal probability of each unit hit of the general population in the sample is fulfilled.

In order to evaluate the psychographic features of the baby food market segmentation, the method of written survey, focus group method (for formulating survey markers) and multivariate factor analysis (analysis of survey results) were applied.

\section{Results}

\subsection{Global social trends that define the development of the Baby food market}

Baby food market is one of the business areas where the formation of consumer preferences depends on moral and spiritual independence from the stereotypical foundations of the consumption society. The most famous researcher of the social and cultural history of food, food systems, nutrition and health, Amy Bentley noted, "the creation and industrialization of baby food in the twentieth century played a central role in shaping American food preferences".

The equality of women in employment and the promotion of personal values and needs, which do not always coincide with family responsibilities, have led to the rapid innovation development of the sphere of baby nutrition. A. Bentley explains it as follows: "Women want it: it's a product of convenience that promotes mobility and flexibility, which is still a theme in American culture" (Bentley, 2014).

However, despite the technological opportunities created, women of the generations of “Xennials” (1975-1985), “Generation Y", “Gen Next” (1980-1994). Give birth twice and three times less than women from Baby Boomer Generation. The level of economic wellbeing cannot be considered as a key to the desire to have children. Along with the fact that the leading countries of the world are ranked highest in the ratings of happiness, quality of life and competitiveness, their place in the Fertility rating last. This indicates a shift in value orientations when feelings of comfort and happiness do not correlate with family responsibilities and reproductive activity. It is logical that in the presence of such high rates of satisfaction with living conditions the conditions for the development of a family institution would be necessary, a high quality of life would be a favorable environment for 
the birth of two or more children. Nevertheless, here too we find rather sad statistics of Divorce rate (table 1) (Reva, 2018; Global competitiveness Report, 2019; World Happiness Report, 2019; The World: Total Fertility Rate, 2019; Quality of Life Index for Country by Numbeo, 2019; Zhao et al, 2020).

Table 1: Comparison of Fertility Rate with indicators of economic and social well-being

\begin{tabular}{|c|c|c|c|c|c|c|c|c|}
\hline \multirow[t]{2}{*}{ Countries } & \multicolumn{2}{|c|}{$\begin{array}{l}\text { Fertility } \\
\text { Rate, } \\
\text { children per } \\
\text { woman }\end{array}$} & \multirow[t]{2}{*}{$\begin{array}{c}\begin{array}{c}\text { Place in } \\
\text { Fertility } \\
\text { Rate }\end{array} \\
2018\end{array}$} & \multirow{2}{*}{$\begin{array}{c}\begin{array}{c}\text { Divorce } \\
\text { rate, } \%\end{array} \\
2018\end{array}$} & \multicolumn{2}{|c|}{$\begin{array}{c}\text { Happiness } \\
\text { Index }\end{array}$} & \multirow[t]{2}{*}{$\begin{array}{c}\text { Global } \\
\text { competitiveness } \\
\text { index, } 2018\end{array}$} & \multirow[t]{2}{*}{$\begin{array}{l}\text { Quality of } \\
\text { life index } \\
\quad 2018\end{array}$} \\
\hline & 1960 & 2018 & & & 2015 & 2018 & & \\
\hline Denmark & 2.5 & 1.7 & 149 & $46 \%$ & 1 & 3 & 10 & 1 \\
\hline Finland & 2.7 & 1.7 & 146 & $56 \%$ & 5 & 1 & 11 & 3 \\
\hline Norway & 2.9 & 1.8 & 142 & $43 \%$ & 4 & 2 & 16 & 8 \\
\hline Switzerland & 2.4 & 1.5 & 174 & $40 \%$ & 2 & 5 & 4 & 2 \\
\hline Iceland & 4.3 & 1.8 & 130 & $39 \%$ & 3 & 4 & 24 & 7 \\
\hline Canada & 3.8 & 1.5 & 172 & $45 \%$ & 6 & 7 & 12 & 18 \\
\hline Netherlands & 3.1 & 1.7 & 152 & $41 \%$ & 7 & 6 & 6 & 6 \\
\hline
\end{tabular}

Sources: systematized by the authors on the basis of qualitative and quantitative International reports indicators (1960, 2015-2018)

It is noteworthy that according to the Human Development Index (HDI) (consisting of life expectancy, per capita income and educational attainment), Norway has been in the lead for 10 consecutive years (Human Development Report, 2019), yet the country ranks 142nd in the world birth rating. And in Niger, which ranks first in the world in birth rate (6.98 per 1 woman), the human development indicator in 2018 is at the last position - 189 . This means a complete gap between the natural birth of children and the indicators of well-being. From now on, happiness figures depend entirely on how early the family regulates the number of children, and it is not a problem that parents are divorced in half of the families. Happiness becomes a pragmatic category, measured in terms of currency. However, we must remember the experiment with mice populations' professor and John Calhoun ("Universe 25"), which aberrant behaviors was in describe overcrowded population density situations and "beautiful ones" to describe passive individuals who withdrew from all social interaction. Then such a phenomenon as "Behavioral sink" was described for the first time: mice were overburdened with material well-being, were subjected to death squared", while the "first death", the death of the spirit, was experienced even during life (Ramsden and Adams, 2008).

Hedonistic paradise for mice with enough food, favorable conditions for reproduction ended paradoxically: mice became aggressive, lost interest in offspring, showed cannibalism, homosexuality and signs of depression.

You can differently refer to the analogies and patterns of mouse and human society. Nevertheless, the fact of spiritual birth and the weakness of the spirit - and by this we mean a high dependence on objects and conditions of comfort - is a natural consequence of a period of prolonged prosperity. The analysis of the baby food market is a kind of marker of the health of society; in both countries with a low happiness index and countries with a high happiness index (also applies to economic indicators). In this study, we sought 
to abstract from the problem of material well-being. This follows from the fact that in poor countries in Africa, the birth of children is most often correlated with the possibility of feeding them (just giving birth), and in economically prosperous countries (Western Europe, Canada, USA, Japan) the fact of having an unplanned baby is considered economically feasible or inappropriate financial investment. Thus pragmatism, not poverty, are the causes of depopulation processes.

\subsection{The economic and psychographic features of Ukrainian consumers of the baby food market}

Ukrainian households spend a significant portion of their total food expenditure on baby food. Moreover, if the family has two children, the costs go up to $45.5 \%$, if three children - up to $53 \%$. The poorest households in Ukraine spend an average of $69 \%$ on food, and the poorest ones spend around 40\% (Expenditure and resources of households of Ukraine 2019). In the share of baby food Ukrainian producers make up only $20 \%$, the rest are from countries such as Germany (47\%), the USA (10\%), the United Kingdom $(10 \%)$, France (8\%), Sweden (6\%), the Czech Republic (6\%), Italy (5\%) and others. But in the structure of consumption of baby food the share of own production accounts for $83 \%$ (mostly due to milk and fermented milk products - 99.6\%; juices and purees - 82\%). In the structure of consumption, the share of milk mixtures from the Ukrainian producer is $46 \%$ (almost $90 \%$ of imported products are four groups of products: dried milk mixtures, cereals, purees, juices). The Ukrainian consumer of baby food shows high interest in domestic products, but the expansion of the production sector is hindered by factors such as lack of its own raw materials base, high cost of raw materials, narrowing of the domestic market due to high migration, low birth rates (in Ukraine, the number of children aged 14 to birth) in 2019 compared to 1990 it decreased by 41.5\%), poverty of the population. By the self-assessment of their income level, $42.1 \%$ of households are constantly denying themselves the most essential, except for food (Self-esteem of households in Ukraine 2018). Thus, the majority of consumers are concerned, first of all, with the problem of availability of baby food, and only then - such privileged qualities as environmental friendliness and organic nature. Moreover, unlike European consumers, consumer awareness of organic food standards is very low.

In this study, we conducted a psychographic analysis of the baby food consumers in order to find the points of interaction of market actors in the context of public interests. China's experience, for example, shows that local and foreign brands can balance the baby food market. There, the CITIC Agrifund Management State Fund in 2018, paying attention to local business development, bought $25.7 \%$ shares of Ausnutria Dairy Corporation Ltd. for $\$ 250$ million, which is a key producer of baby food among local businesses.

A focus group method was used in order to select the best markers (issues) of consumer preferences for baby food, consisting of student representatives, mothers of many children, representatives of public authorities (child services), a marketing agency and representatives of public organizations (protection of orphans rights, help for large families, protection and promotion of family values). As a result, 39 markers of psychographic characteristics of potential consumers on the baby food market were selected. Thus, the sample was 634 persons - representatives of households with one child under 3 years (366 persons - 57.7\%), two children under 5 years $(253-39.9 \%)$, three or 
more children under 8 years (15 persons - 2.3\%).

Table 2: Demographic, socio-economic structure of respondents

\begin{tabular}{|l|c|}
\hline Variable & Entire population examined (N=634) \\
\hline Sex & 119 \\
\hline Men & 515 \\
\hline Women & \\
\hline Age & 36 \\
\hline Middle age & 53 \\
\hline Maximum age & 19 \\
\hline Minimum age & \\
\hline Marital status & 423 \\
\hline Married & 182 \\
\hline Divorced & 27 \\
\hline Single & 2 \\
\hline Widow/er & \\
\hline Number of children & 366 \\
\hline 1 child under 3 years & 253 \\
\hline 2 children under 5 years & 15 \\
\hline 3 children and more than 8 years & \\
\hline Average monthly income & 172 \\
\hline Up to 5000 UAH & 221 \\
\hline $5000-7000$ UAH & 159 \\
\hline $7000-10000$ UAH & 63 \\
\hline $10000-15000$ UAH & 19 \\
\hline More than 15000 UAH & \\
\hline Accommodation in the region & 153 \\
\hline Village & 481 \\
\hline City & \\
\hline
\end{tabular}

Source: field research by the authors, 2019

Among 634 respondents, 515 were women and 119 were men. The youngest participant in the survey was 19 years, the oldest was 53 years. The average age of the respondents was 36 years. Of the 634 household representatives, 211 were single (divorced, single or widowed), 151 of whom lived separately from their parents and ex-husband or wife, i.e. had no other adult helpers on the household.

The target sample confirmed national trends in household characteristics with children. In Kherson region, in 2018, 25.8\% of households existed without one or both parents. Of these, $36.6 \%$ are households with children under 7 years. $75.1 \%$ of households have one child, two children $-21.4 \%$, three children $-3.1 \%$, four or more $-0.4 \%$. Households with children under 3 years old - only 7.5\% in large cities and $6 \%$ in large cities. In the structure of the total expenditures of households in Ukraine - almost $50 \%$ is the cost of food. $44 \%$ of households in 2016 and 38\% in 2017 (by self-perceived) were constantly denying themselves the necessities other than food. $70.7 \%$ of households are poor; $44.1 \%$ of households expect their financial status to deteriorate in the next 12 months.

The marker of a certain life position was the choice of suitable options (Table 3 ). 
Table 3: Composition of variables in survey data

\begin{tabular}{|c|c|c|}
\hline Variable & Question & Responses in the survey \\
\hline $\begin{array}{l}\text { X17 (the degree of } \\
\text { priority of the "family" } \\
\text { over the priority of the } \\
\text { "career") }\end{array}$ & $\begin{array}{l}\text { "Choose a position close } \\
\text { to your worldview": }\end{array}$ & $\begin{array}{l}\text { A1: Having children requires complete } \\
\text { dedication, despite my career aspirations } \\
\text { A2: Career progression may be delayed by } \\
\text { maternity leave } \\
\text { A3: It is possible to combine work with } \\
\text { childcare } \\
\text { A4: Careers first then children. }\end{array}$ \\
\hline $\begin{array}{l}\text { X37 (a measure of } \\
\text { comfort from the } \\
\text { suppression of self- } \\
\text { interest) }\end{array}$ & $\begin{array}{l}\text { "Choose from the } \\
\text { suggested items": }\end{array}$ & $\begin{array}{l}\text { A1: For the sake of the children, it is } \\
\text { possible to abandon many of the old } \\
\text { shopping habits and needs (new clothes, } \\
\text { summer vacations, cars, premises repairs, } \\
\text { appliances, etc.) } \\
\text { A2: For the sake of children, it is possible } \\
\text { to give up luxury goods } \\
\text { A3: I try to reconcile my own and the } \\
\text { child's needs on a sufficient level } \\
\text { A4: There are paramount needs of parents } \\
\text { that are hard to ignore. }\end{array}$ \\
\hline $\begin{array}{l}\text { X35 (completeness and } \\
\text { harmony of relationships } \\
\text { in the family) }\end{array}$ & $\begin{array}{l}\text { Evaluate the position: } \\
\text { "We support unplanned } \\
\text { birth of children as the } \\
\text { fulfillment of the family } \\
\text { main mission..." }\end{array}$ & $\begin{array}{l}\text { A1: I absolutely agree } \\
\text { A2: Maybe. Rather yes } \\
\text { A3: Theoretically agree } \\
\text { A3: I do not agree } \\
\text { A4: Strongly disagree }\end{array}$ \\
\hline
\end{tabular}

Source: worked out by the authors

This study aimed to unlock the potential for long-term consumption of baby food at the expense of the extended life cycle of a "full-nest type 1" family. This is a major factor in the formation of long-term commitment of consumers to the brand of the manufacturer and the firm position of the enterprise in the baby food market.

The respondents answered a written survey that included the markers that focused on expectations, reactions, and emotional state in the context of variations in material, psychological, and physiological states at different points in the life cycle of parenthood. Given the poor reliability of logical and rational questions, the markers included associative questions, which should be used based on the particular psycho-emotional status of most respondents (mostly women). In order to increase the reliability of the psychographic study, the demographic characteristics are included in the general array: gender, year of birth, occupation, average monthly family expenses on food, religious affiliation. It is important to note, that religious worldview is a latent moral imperative of consumer behavior culture (Pavlova, 2019; Tan, 2020).

The study obtained a $634 \times 39$ matrix, which was analyzed using principal components analysis (PCA). Singled out five major components (with eigenvalues from 5.11 to 1.20), explaining $62.0 \%$ of the total variance, verification using the Kaiser - Meyer - Olkin Measure of Sampling Adequacy (0.759) confirmed the appropriateness of factor analysis. Rotation converged in 8 iterations. Factors with an eigenvalue above 1 were considered (table 4). 
Table 4: Total Variance Explained

\begin{tabular}{|c|c|c|c|c|c|c|c|c|c|}
\hline \multirow{2}{*}{$\begin{array}{c}\text { Com- } \\
\text { ponent }\end{array}$} & \multicolumn{3}{|c|}{ Initial Eigenvalues } & \multicolumn{3}{c|}{$\begin{array}{c}\text { Extraction sums of squared } \\
\text { loadings }\end{array}$} & \multicolumn{3}{c|}{$\begin{array}{c}\text { Rotation Sums of Squared } \\
\text { Loadings }\end{array}$} \\
\cline { 2 - 10 } & Total & $\begin{array}{c}\text { \% of } \\
\text { Variance }\end{array}$ & $\begin{array}{c}\text { Cumulative } \\
\text { \% }\end{array}$ & Total & $\begin{array}{c}\text { \% of } \\
\text { Variance }\end{array}$ & $\begin{array}{c}\text { Cumulative } \\
\%\end{array}$ & Total & $\begin{array}{c}\text { \% of } \\
\text { Variance }\end{array}$ & $\begin{array}{c}\text { Cumulative } \\
\%\end{array}$ \\
\hline 1 & 5.112 & 25.497 & 25.497 & 5.112 & 25.497 & 25.497 & 4.383 & 23.534 & 23.534 \\
\hline 2 & 3.145 & 11.627 & 37.124 & 3.145 & 11.627 & 37.124 & 3.515 & 10.551 & 34.085 \\
\hline 3 & 2.732 & 9.515 & 46.639 & 2.732 & 9.515 & 46.639 & 3.070 & 9.877 & 43.962 \\
\hline 4 & 1.534 & 8.345 & 54.984 & 1.534 & 8.345 & 54.984 & 1.839 & 9.372 & 53.334 \\
\hline 5 & 1.206 & 7.103 & 62.087 & 1.206 & 7.103 & 62.087 & 1.325 & 8.753 & 62.087 \\
\hline 6 & 0.927 & 4.145 & 66.232 & & & & & & \\
\hline 7 & 0.845 & 3.211 & 69.443 & & & & & & \\
\hline 8 & 0.751 & 3.116 & 72.559 & & & & & & \\
\hline 9 & 0.727 & 2.194 & 74.753 & & & & & & \\
\hline 10 & 0.713 & 2.176 & 76.938 & & & & & & \\
\hline$\ldots$ & $\ldots$ & $\ldots$ & $\ldots$. & & & & & & \\
\hline 39 & 0.013 & 0.030 & 100 & & & & & & \\
\hline
\end{tabular}

Source: Extraction Method: Principal Component Analysis with rotation methods of V arimax (abridged version of the table)

Figure 1 shows a graph of decreasing eigenvalues of matrix correlation, it visualizes the relative importance of factors. A five-component solution was proposed by the scree plot.

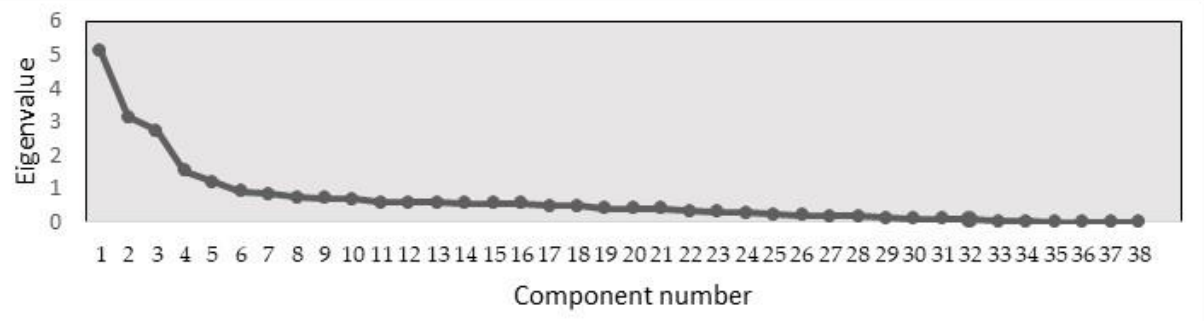

Figure 1: Data Scree Plot

Source: own research

The five main components were linguistically described. Each of the five components combined features that explain the unique combination of characteristics (table 5). The components can be used as integrated psychographic features of consumer preferences in the baby food market.

Table 5: Integrated psychographic characteristics of baby food products consumers

\begin{tabular}{|l|l|c|l|}
\hline \multirow{N}{*}{$\begin{array}{l}\text { Integrated Psychographic } \\
\text { characteristics }\end{array}$} & $\begin{array}{c}\text { Factor } \\
\text { loads }\end{array}$ & Key indicators \\
\hline f1 & $\begin{array}{l}\text { The pressure of life and the ability to } \\
\text { withstand it }\end{array}$ & 0.773 & X3 - number of children in the family \\
\cline { 3 - 4 } & 0.812 & X27 - dynamics of career advancement \\
\cline { 3 - 4 } & 0.642 & X22 - the average monthly cost of food \\
\cline { 3 - 4 } & 0.515 & X12 - availability of household helpmates \\
\cline { 3 - 4 } & 0.485 & X2 - marital status (married, divorced) \\
\hline
\end{tabular}




\begin{tabular}{|c|c|c|c|}
\hline No & $\begin{array}{l}\text { Integrated Psychographic } \\
\text { characteristics }\end{array}$ & $\begin{array}{l}\text { Factor } \\
\text { loads }\end{array}$ & Key indicators \\
\hline \multirow[t]{6}{*}{$\mathrm{f} 2$} & \multirow[t]{6}{*}{ Pressure of own needs and aspirations } & 0.747 & X20 - the cost of annual holiday expenses \\
\hline & & 0.616 & X3 - number of children in the family \\
\hline & & 0.554 & $\begin{array}{l}\text { X25 - cost of annual expenses for } \\
\text { rehabilitation, aesthetic medicine, beauty }\end{array}$ \\
\hline & & 0.549 & $\begin{array}{l}\text { X21 - cost of construction, repair, } \\
\text { purchase of home appliances }\end{array}$ \\
\hline & & 0.503 & $\begin{array}{l}\text { X23 - cost of annual clothing costs for the } \\
\text { whole family }\end{array}$ \\
\hline & & 0.474 & $\begin{array}{l}\text { X30 - the cost of annual development, } \\
\text { education and leisure expenses for children }\end{array}$ \\
\hline \multirow[t]{4}{*}{ f3 } & \multirow[t]{4}{*}{ The birth priority of the next baby } & 0.769 & $\begin{array}{l}\text { X35 - completeness and harmony of } \\
\text { relationships in the family }\end{array}$ \\
\hline & & 0.714 & X15 - completeness of religious outlook \\
\hline & & 0.610 & $\begin{array}{l}\text { X33 - origin from a family with a certain } \\
\text { number of children }\end{array}$ \\
\hline & & 0.523 & $\begin{array}{l}\text { X17 - the degree of priority of "family" } \\
\text { over priority of "career" }\end{array}$ \\
\hline \multirow[t]{5}{*}{$\mathrm{f} 4$} & \multirow[t]{5}{*}{$\begin{array}{l}\text { A measure of psycho-emotional } \\
\text { satisfaction from maternal function }\end{array}$} & 0.802 & $\begin{array}{l}\text { X19 - a measure of psychological comfort } \\
\text { in the family }\end{array}$ \\
\hline & & 0.734 & X4 - year of birth \\
\hline & & 0.729 & $\begin{array}{l}\text { X37 - a measure of comfort from the } \\
\text { suppression of self-interest }\end{array}$ \\
\hline & & 0.617 & $\begin{array}{l}\text { X33 - origin from a family with a certain } \\
\text { number of children }\end{array}$ \\
\hline & & 0.537 & $\begin{array}{l}\text { X35 - completeness and harmony of } \\
\text { relationships in the family }\end{array}$ \\
\hline \multirow[t]{4}{*}{ f5 } & \multirow{4}{*}{$\begin{array}{l}\text { Sustainable (steady) representation } \\
\text { and imitation of traditions }\end{array}$} & 0.839 & X16 - food priority (home, purchase) \\
\hline & & 0.812 & X11 - occupation (housewife / working \\
\hline & & 0.703 & X22 - the average monthly cost of food \\
\hline & & 0.510 & X18 - commitment to healthy eating \\
\hline
\end{tabular}

Source: worked out by the authors

The first component, "Life pressure and ability to withstand" (25.5\% of the variance), combined the most alarming features related to family financial status. High factor loadings of signs X3 (Factor load $(\mathrm{FL})=0.773), \mathrm{X} 27(\mathrm{FL}=0.812), \mathrm{X} 22(\mathrm{FL}=0.642)$ indicate that the psychographic features of consumer preferences of potential buyers of baby food products are significantly determined by demographic indicators of wealth, marital status, and number of children born. The last indicator, unlike in Africa, for many decades in Ukraine has been correlated with the dynamics of career advancement and income level.

For example, the result of the absence of such a correlation in Africa is the forecasts for Unicef data in the period from 2016 to 2030 infant population of Africa will increase be $170 \mathrm{mln}$ people. Instead, the number of children in Europe, Asia and Latin America will drop by 48 million (Generation 2030 Africa 2.0 2017).

The second factor "Pressure own needs and aspirations" (11.6\% variance) grouped signs that show the possible dominance of individualistic values, which could potentially 
compete with the desire to have less income but a greater number of children. Here is the paradox: on the one hand, consumer perfectionism is inherent in a more affluent class of buyers of baby food products, from here they have better opportunities to have three or more children. However, this is hypothetical. In these lives, these wealthy buyers, in $90 \%$ of cases, give birth to 1-2 children, and eventually cease to be interested in baby food at the first stage of the young family's life cycle. Bigger income only means higher costs for housing development's conditions aesthetic needs, training, but not to increase the number of children, and hence the cost of their food. In $30 \%$ of cases studied population second and third child was not planned in families with revenue of more than 1200 USA dollars. First, it indicates a sense of danger for their own children (the result of long-term economic policy in Ukraine), and secondly, an increase in the pragmatic and hedonistic values of representatives of the "full nest $(1,2,3)$ " classes (over the life cycle of family).

The third factor "Priority birth of the next child" ( $9.5 \%$ variance) showing signs of absolute priority "family" or "career" based on completeness of relationships within the family, religious worldview, the origin from a large or small family. It turned out that those respondents who had younger siblings were more likely to have a "family" priority than a "career" priority. However, the most active consumers of baby food (canned food, dried cereals, yoghurts, cottage cheese) were mothers who are planning a business career or, already having young children, work. Despite this activity, the likelihood that they will last the life cycle of a "full nest 1" (children under 6 years) is very low. Having 1-2 babies, they quickly move into the "full nest $(2,3)$ " category (children after 6 years) and no longer return to this category. The religious outlook, deep and consistent, with great probability brings this category closer to many, and hence, in times of scarcity, to the active consumption of baby food (cheese, yogurt, canned food, dried cereals).

The fourth factor, "Measure of psycho-emotional satisfaction from fulfilling maternal function" (8.3\% of the variance), included signs of psychological comfort in the family, satisfaction / discomfort from restraining their own needs. The high factor load in this component demonstrated the significance of the age category $(\mathrm{FL}=0.734)$. Only $15 \%$ of young women surveyed are ready to exercise with pleasure and comfort. Suppression of self-interest is perceived as an uncomfortable condition that violates the harmony of relationships in the family in $85 \%$ of cases. The psycho-emotional state of the youngest parents reflected the selfish aspirations, freedom of choice, hedonistic cultural values, tendencies of pragmatism, which very much "weakened the spirit" at the level of endurance, sacrifice, patience, dedication, selflessness. Again, the long-lived past of representatives of the "full nest" positively influences the decision to give birth without regard to the lack of time, money, and economic instability. Many baby food products are targeted at a group of consumers who are guided by "psycho-emotional satisfaction from fulfilling the maternal function". For example, consumer awareness of the benefits of consumption of canned, etc. goods with highest quality. This is their knowledge of the balance of the composition of products, tight packaging, the absence of pesticides in fruits and vegetables, hormones and harmful bacteria in meat, heavy metals in fish and more. It is about the fact that there are a certain number of parents who refuse but buy the best for their child, while having small financial resources.

"Sustainable imagination and tradition" (7.1\% variance) factor has the most formalized description. The priority of a homemade meal is more likely to be influenced by the 
decision not to do without the goods from the store. There is a direct connection with the occupation $(\mathrm{FL}=0.812)$. A housewife with a high average monthly food expenditure, with the priority of household food, is not an active consumer of "store" baby food. Instead, there is a link between the priority of purchased food, the commitment to a healthy lifestyle and frequent purchases of baby food. It formed special relationships with brands based (founded) on the special confidence of the consumer to the company (the duration of the company, good reviews in social networks and the Internet, the country of origin, their intuitive sense).

\subsection{Consumption risk zones and possible foresight solutions}

The results revealed can significantly affect the repositioning of the product, the expansion of the target market, the coding system of advertising information - all based on the psychology of consumption on five selected factors. The study identifies consumption risk areas in the target segments. It is possible to propose the introduction of such communication tool as "social PR-project" ("green" PR), the object of influence of which is the area of social relations of target groups of consumers. This is an effective way to promote fashion (promotion) socio important character. During the promotion of social projects recorded positive image and the company. The purpose of such a social PR project is to promote universal (family) values, principles, and knowledge that is important for the whole of human society. The objectives of the project are to formulate a strategic positioning line through key messages that need to be communicated to the target audience. Figure 2 shows the identified areas of consumption risk in the segments of potential consumers identified during the psychographic study.

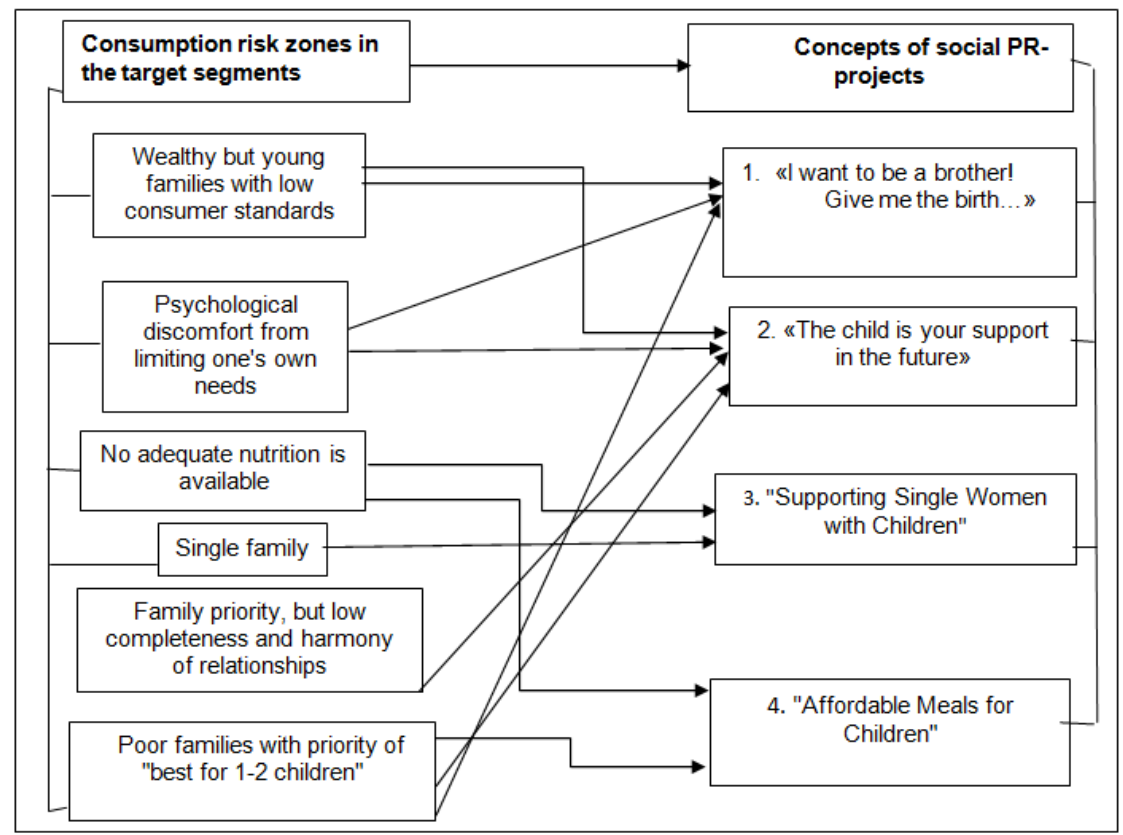

Figure 2: Strategic risk zone consumption of baby food and the concept of social PR-projects

Source: developed by authors. 
The strategic approach of interaction of companies with the targeted segment aims to expand the length of relationship with consumers. The most profitable target segment can be expanded by extending the family life cycle to "full nest 1 (with children under 6)". Within the target segments of baby food consumers, there is a conglomerate of psychological, material and personal obstacles in the continuation of the "young parents" cycle. This is a consequence of the continued neglect of the problems of sociodemographic development. Combining the efforts of the state and business can, in the long run, through communication, influence not only on consumer preferences (benefits of baby food manufacturers), but also on the sphere of family relations (increase of fertility, strengthening of family values). Such Foresight - the project is essential tool for solving pressing social problems. In this case, the marketing strategy of an enterprise assumes the interest of the domestic business in making its consumers wealthy, happy and giving birth to more children. The social position of the company becomes part of its image, business reputation. From the point of view of the state strategic vision, it is very rational to involve business in solving social problems. The retail segment (retailers), baby food manufacturers, and government institutions may jointly fund such projects. Each specific consumption risk zone, depicted in Figure 1, needs a specific concept of social PR-project in. Inside each of these concepts is an arsenal of information communications and funding sources. For example, the concept of "I want to be a brother! Give me the birth..." aims to promote multiplicity. "The child is your support in the future" - a social PR-project aimed at increasing the able-bodied population in the conditions of intensive aging of the population (increasing the share of the elderly relative to young people). This project also provides free, long-term psychological assistance for families on the verge of divorce. "Affordable meals for children" is a sponsorship of dairy cuisine (possibly free meals for children from single families). "Support for single women with children" - in addition to free meals (such as schools and kindergartens), there will also be free babysitting for working mothers. Sponsorship opportunities for social PR-projects set. However, these private initiatives need to be integrated with national strategic policies, national and regional programs and plans.

\section{Discussion}

Over the years of independence (since 1991) Ukraine has introduced many programs and reforms to transform the economic environment in accordance with global processes. Unfortunately, the functional core of reforms implementation and opportunistic political decisions was not put at the forefront the social adaptation of the population to crushing changes, especially in the sphere of employment and economic processes. In a new dimension, the importance of human values is being tested by means of financial benefit. The atomization of public and private interests led to the separation of public and personal goals. The state does not have any long-term targeted interaction with business structures. Therefore, business structures are not considered as subjects of the implementation of state and regional programs. The business sector should become aware of its involvement in the implementation of important state tasks, otherwise, this is fraught with multidirectional movement and discord. Business structures need motivation to follow state development plans. They need a developed domestic consumption market. 
Society, however, needs a business motivated by the public interest. And the state should ensure the implementation of the consensus of these interests. A platform for long-term targeted interaction can be a foresight design system. For example, there are alarming signals: low birth rates, a nationwide crisis in family relations, high food costs, the dominance of foreign companies at the food market. Each of these problems requires the government's attention, accordingly: the state program to increase the birth rate; introducing programs to promote family values at schools and universities; expanding the network of preferential (free) catering for poor families; equity participation of state funds in companies that produce food and, in particular, baby food. An analysis of the psychographic characteristics of baby food consumers confirmed the following. Due to the systemic and prolonged indifference of the State to the problems of young families, people began to regard the birth of children as an expensive inaccessible investment. In addition, it is necessary to classify the production of baby food as strategic, possibly in the future in the context of the National Strategy for Healthy Nutrition, which can be implemented only in the unification of state interests with the interests of business structures.

\section{Conclusions}

According to a study of the behavior of potential consumers in the baby food market, there are five main motivating factors. These factors to a different extent (on the basis of key indicators) determine the psychographic characteristics of baby food consumers in the context of the pressure of life circumstances and their ability to withstand, the pressure of their own needs and aspirations, the possible priority of the next child birth, the degree of psycho-emotional satisfaction from performing maternal function and following the traditions. If you look in depth at the key indicators of each factor, you can see a number of social and psychological distortions that can be considered as risk areas for consumption in the target segments. These risk areas need priority in the strategic interaction of business structures and organizations representing state interests in the field of social development. However, as noted at the beginning of the article, family value priority indicators do not determine the country's level of happiness or social wellbeing. The paper proposes the implementation of four social PR projects, each aimed at specific consumption risk areas in the target segments. The study proposes to integrate the marketing communication policy of baby food manufacturers and government policies in the field of fertility support in Ukraine, based on the principles of Foresight engineering for the social projects implementation. Thus, national strategic policies, national and regional programs and plans should include a system of bilateral motivation measures: domestic enterprises in the context of the internal market development, potential consumers in the implementation of policies of extended demographic reproduction.

\section{Acknowledgments}

The authors would like to thank the editor, the associate editor, and the anonymous reviewers for their guidance and encouragement in the review process. 


\section{References}

Abdullah, S., Joireman, J., \& Sprott, D. (2012). Building consumer self-control: The effect of self-control exercises on impulse buying urges. Marketing Letters, 23(1), 61-72. https://doi.org/10.1007/s11002011-9135-4.

Allenby, G., Fennell, G., Bemmaor, A. et al. (2002). Market Segmentation Research: Beyond Within and Across Group Differences. Marketing Letters, 13, 233-243. https://doi.org/10.1023/A:1020226922683.

Arnould, E., \& Thompson, C. (2018). Consumer Culture Theory. SAGE Publications Ltd.

Baudrillard, J. (1998). The Consumer Society: Myths and Structures. SAGE Publications Ltd, London.

Baumeister, R. F., Bratslavsky, E., Muraven, M., \& Tice, D. (1998). Ego Depletion: Is the Active Self a Limited Resource? Journal of Personality and Social Psychology, 74(5), 1252-1265. https://doi.org/10.1037/00223514.74.5.1252.

Bearden, W., \& Kelly, L. H. (2012). How Low Spending Control Harms Consumers. Journal of the Academy of Marketing Science, 40(1), 181-193. https://doi.org/10.1007/s11747-011-0282-1.

Becker, L., \& Jaakkola, E. (2020). Customer experience: fundamental premises and implications for research. Journal of the Academy of Marketing Science, 48, 630-648. https://doi.org/10.1007/s11747-019-00718$\mathrm{x}$.

Bentley, A. (2014). Inventing Baby Food: Taste, Health, and the Industrialization of the American Diet. University of California Press, Oakland, U.S.A.

Birkhead, B. (2001). Behavioural segmentation systems: A perspective. J Database Mark Cust Strategy Manag, 8, 105-112. https://doi.org/10.1057/palgrave.jdm.3240024.

Druzhynina, V., Viedienina, Y., Sakun, L., \& Likhonosova, G. (2020). Creative Analysis of Innovation as a Catalizer of Socialization of Structural Change. European Journal of Sustainable Development, 9(2), 349. https://doi.org/10.14207/ejsd.2020.v9n2p349.

Eisingerich, A., Marchand, A., Fritze, M., \& Dong, L. (2019). Hook vs. hope: How to enhance customer engagement through gamification. International Journal of Research in Marketing, 36(2), $200-215$. https://doi.org/10.1016/j.ijresmar.2019.02.003.

Expenditure and resources of households of Ukraine in 2018. (2019). Retrieved January 15, 2020 from http://www.ukrstat.gov.ua/druk/publicat/kat_u/2019/zb/06/zb_vrdu2018.pdf.

Gallagher, J. (2018). "Remarkable" decline in fertility rates. BBC News. Retrieved February 7, 2020 from https://www.bbc.com/news/health-46118103.

Géczy, P., Izumi, N., Akaho, S., \& Hasida, K. (2007). Usability Analysis Framework Based on Behavioral Segmentation. In: Psaila G., Wagner R. (eds) E-Commerce and Web Technologies. EC-Web 2007. Lecture Notes in Computer Science, vol 4655. Springer, Berlin, Heidelberg. https://doi.org/10.1007/978-3-54074563-1 4.

Generation 2030 Africa 2.0. (2017). Prioritizing investments in children to reap the demographic dividend. Retrieved March 01, 2020 from https:/ / data.unicef.org/resources/generation-2030-africa-2-0/.

Global competitiveness Report 2017-2018. (2019). Retrieved March 16, 2020 from http://www3.weforum.org/docs/GCR2017-

2018/05FullReport/TheGlobalCompetitivenessReport2017\%E2\%80\%932018.pdf.

Global infant nutrition market size (2019). Retrieved April 07, 2020 from https://www.statista.com/statistics/719436/global-market-size-baby-formula/.

Hart, P., \& Royne, M. (2017). Being Human: How Anthropomorphic Presentations Can Enhance Advertising Effectiveness. Journal of Current Issues \& Research in Advertising, 38(2), 129-145. https://doi.org/10.1080/10641734.2017.1291381.

HDR. Human Development Report 2018. (2019). United Nations Development Program. Retrieved April 22, 2020 from http://worldpopulationreview.com/countries/hdi-by-country/ and http://hdr.undp.org/en/2018update.

Heerah, K., Woillez, M., Fablet, R. et al. (2017). Coupling spectral analysis and hidden Markov models for the segmentation of behavioural patterns. Mov Ecol, 5, 20. https://doi.org/10.1186/s40462-017-0111-3.

Herak, I., Kervyn, N., \& Thomson, M. (2020). Pairing People with Products: Anthropomorphizing the Object, Dehumanizing the Person. Journal of Consumer Psychology, 30(1), 125-139. https://doi.org/10.1002/jcpy.1128. 
Kleszczyński, K. (2019). Games and the Future of Man. Gamification as a Transhumanist Program. Future Human Image, 12, 53-62. https://doi.org/10.29202/fhi/12/4.

Nguyen, T., \& Paswan, A. (2013). Self-control and Sustainable Consumer Behavior. In Ideas in Marketing: Finding the New and Polishing the Old, Kubacki, K. (Ed.) (pp. 560-563). Springer International Publishing. https://doi.org/10.1007/978-3-319-10951-0.

Pavlova, O. (2019). Politically-Technological Potential of Cultural Practices in Ukrainian Perspective. Ukrainian Policymaker, 2, 20-26.

Quality of Life Index for Country by Numbeo 2018. (2019). Retrieved May 03, 2020 from https://www.numbeo.com/quality-of-life/rankings_by_country.jsp?title=2018-mid (accessed on 21 January 2020).

Ramsden, E., \& Adams, J. (2008). Escaping the Laboratory: The Rodent Experiments of John B. Calboun \& Their Cultural Influence. Department of Economic History London School of Economics, Houghton Street London.

Reva, N. (2018). Logic, Reasoning, Decision-Making. Future Human Image, 10, 76-84. https://doi.org/10.29202/fhi/10/8.

Richins, M. (2017). Materialism pathways: The processes that create and perpetuate materialism. Journal of Consumer Psychology, 4(27), 480-499. https://doi.org/10.1016/j.jcps.2017.07.006.

Schmitt, B. (2013). The consumer psychology of customer-brand relationships: Extending the AA Relationship model. Journal of Consumer Psychology, 23(2), 249-252. https://doi.org/10.1016/j.jcps.2013.01.003.

Scopelliti, J., \& Huh, Y. (2020). Exerting Self-Control \& Sacrificing. Pleasure. Journal of Consumer Psychology, 30(1), 181-200. https://doi.org/10.1002/jcpy.1142.

Self-esteem of households in Ukraine on their income level (according to a sample household survey conducted in January 2018) statistical digest. (2018). State statistics service of Ukraine. Retrieved May 11, 2020 from http://www.ukrstat.gov.ua/druk/publicat/kat_u/2018/zb/06/zb_sdurd2017pdf.pdf.

Shah, S. K. (2008). Performance Modeling and Algorithm Characterization for Robust Image Segmentation. Int J Comput Vis, 80, 92-103. https://doi.org/10.1007/s11263-008-0130-z.

Slater, D. (1999). Consumer Culture and Modernity. 1st ed. Cambridge: Polity Press.

Tan, Y. (2020). Toward a law of healthy peoples: From the Perspective of the Right to Health. Future Human Image, 13, 113-125. https://doi.org/10.29202/fhi/13/12.

The World: Total Fertility Rate 2018. (2019). Retrieved May 25, 2020 from http: $/ /$ www.geoba.se $/$ population.php?.pc $=$ world\&page $=1 \&$ type $=010 \& \mathrm{st}=$ rank\&asde $=\&$ year $=2018$.

U.S. Pet Industry Spending Figures \& Future Outlook (2019). Retrieved June 03, 2020 from https://www.americanpetproducts.org/press_industrytrends.asp.

Ukraine population 2018. (2019). State Statistics Service of Ukraine. Retrieved January 23, 2020 from http://www.ukrstat.gov.ua/operativ/operativ2007/ds/nas_rik/nas_u/nas_rik_u.html.

World Happiness Report 2015, 2018. (2019). Retrieved April 24, 2020 from http://worldhappiness.report/ed/2019/.

Yang, L. W., Aggarwal, P., \& McGill, A. L. (2020). The 3 C's of anthropomorphism: Connection, comprehension, and competition. Consumer Psychology Review, 3(1), 3-19. https://doi.org/10.1002/arcp.1054.

Zhao, H., Lan Jiang, L., \& Su, C. (2020). To Defend or Not to Defend? How Responses to Negative Customer Review Affect Prospective customers' Distrust and Purchase Intention. Journal of Interactive Marketing, 50, 45-64. https://doi.org/10.1016/j.intmar.2019.11.001. 